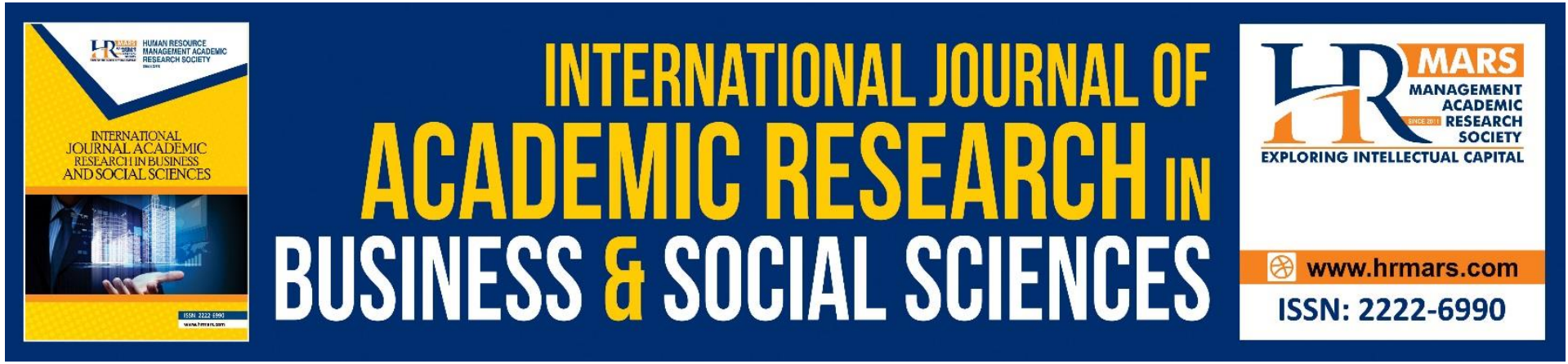

\title{
The Development of a Conceptual Framework for Customer Loyalty Among Users of Mobile Loyalty Programmes
}

Sharlini Seridaran, Mohd Nazri Mohd Noor

To Link this Article: http://dx.doi.org/10.6007/IJARBSS/v11-i7/10544

DOI:10.6007/IJARBSS/v11-i7/10544

Received: 25 May 2021, Revised: 28 June 2021, Accepted: 14 June 2021

Published Online: 30 July 2021

In-Text Citation: (Seridaran \& Noor, 2021)

To Cite this Article: Seridaran, S., \& Noor, M. N. M. (2021). The Development of a Conceptual Framework for Customer Loyalty Among Users of Mobile Loyalty Programmes. International Journal of Academic Research in Business and Social Sciences, 11(7), 892-906.

Copyright: (c) 2021 The Author(s)

Published by Human Resource Management Academic Research Society (www.hrmars.com)

This article is published under the Creative Commons Attribution (CC BY 4.0) license. Anyone may reproduce, distribute, translate and create derivative works of this article (for both commercial and non-commercial purposes), subject to full attribution to the original publication and authors. The full terms of this license may be seen at: http://creativecommons.org/licences/by/4.0/legalcode

Vol. 11, No. 7, 2021, Pg. 892 - 906

http://hrmars.com/index.php/pages/detail/IJARBSS

JOURNAL HOMEPAGE

Full Terms \& Conditions of access and use can be found at http://hrmars.com/index.php/pages/detail/publication-ethics 


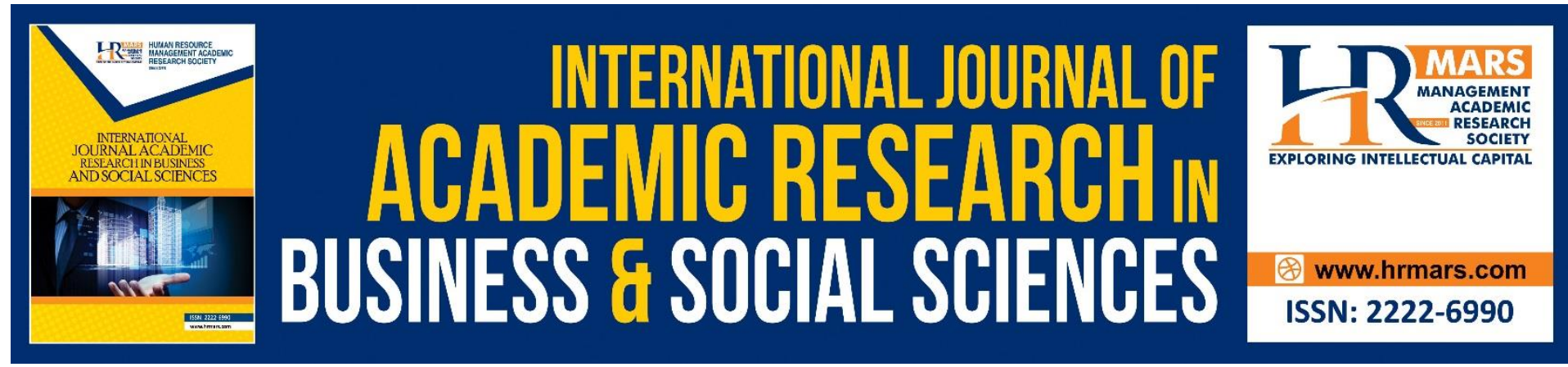

\title{
The Development of a Conceptual Framework for Customer Loyalty Among Users of Mobile Loyalty Programmes
}

\author{
Sharlini Seridaran, Mohd Nazri Mohd Noor \\ Open University Malaysia, Malaysia
}

\begin{abstract}
The purpose of this study is to conceptually examine existing academic literature within the last ten years (2011 to 2021) that would explain customer loyalty within the branded mobile loyalty programmes. The growing need for companies to build a sustainable relationship with customers translated into the development of mobile loyalty programmes in various industries. This paper also aims to establish a conceptual framework focusing on the antecedents for customer loyalty while associating a model called Theory of Planned Behaviour as the basis to comprehend customers' intention to perform specific behaviour favouring the brands. Some of the most commonly used variables in the literatures are perceived ease of use, attitude, subjective norm and engagement. The recommended framework in this study may serve as a guide for marketing practitioners to improve the existing strategies of loyalty programmes to stay relevant and competitive.
\end{abstract}

Keywords: Customer Loyalty, Mobile Loyalty Programmes, Theory of Planned Behaviour

\section{Introduction}

The role of marketing has never been more important than how it is today as organizations ranging from large multi-national to small entrepreneurial and local businesses recognize that marketing is an important business function (Belch \& Belch, 2018). In recent years, companies strive to build long-lasting relationships with customers with the intention to be competitive and at the same time ensure effective use of marketing budget. This is because many companies are aware that acquiring a new customer can be more expensive than sustaining an existing one. Loyalty programmes have also been a common customer relationship management tool for businesses to maintain relationships with customers (Hutchinson et al., 2015). Before the heady days of smartphones and digital age advertising, loyalty programmes were often used within the airline or retail industry. Customers were provided with physical cards and expected to repeat purchases for free rewards (Mulqueen, 2018). In fact, it is still common within some industries or countries where physical cards are distributed. For instance, Petronas, Malaysia's leading oil and gas company distributes its loyalty card called Mesra loyalty programme to customers who visit the petrol stations and rewards customers with three points for every litre of fuel purchased (Chan, 2017). However, in recent time, Petronas launched its direct pump fuel payment application for its customers which enable them to earn points and redeem fuel at Petronas stations with the application 
(Ker, 2020). Customer loyalty programmes can be incredibly valuable to any organization as they bring additional recurring revenue to the company and at the same time make loyal customers content with rewards (Kihlstrom, 2018). In certain circumstances, a physical card may be the best strategy for the company, and for some it may not be. Therefore, companies must evaluate their own strategies and implement a loyalty programme accordingly. From a customer's point of view, it should only bring a good customer experience, enhance their relationship with the brand and customer satisfaction. This adds up to having long-term relationships and maintaining profitability and sustainability for companies.

Besides, it is questionable to rely customer loyalty on loyalty programmes because a study revealed that customer is loyal to a brand when 86 percent recommend a company to friends and family, 66 percent are likely to write positive feedback and 46 percent remain loyal even after a bad experience (KPMG, 2019). Loyalty programmes allow customers to provide feedback and with the insights, brands can stay relevant and fine-tune the marketing strategies to engage with customers said Emily Wong, the Regional Marketing Director for Watson Group (Yuen, 2019). Customer loyalty is undoubtedly a crucial concept for brands to look into, particularly in Malaysia as 47 percent of Malaysians switch brands when offered price reductions or promotions, 49 percent will switch when they see better value for money and 35 percent will stick with trusted brands if the brands can provide better quality (Warc, 2019). Customer loyalty is therefore seen as a crucial element to be analysed by brands in order to sustain their customers. Offerings through loyalty programmes enable customers not to switch brands as it would encourage them to spend more with the company.

On the other hand, with so much technological advancement and competition, it is challenging for companies to ensure they remain relevant and provide the value that customers signed up for within the loyalty programme. According to Mulqueen (2018), loyalty programmes are becoming far more appropriate, sophisticated, and engaging than ever before and all these due to the growth in technology. A recent study revealed that 77 percent of Americans own smartphones, the same percentage are online daily, and more than 90 percent of customers who use digital wallets say they are likely to keep personalized rewards in their e-wallet or mobile application (Burnett, 2019). There seems to be a solid number of American customers who are exposed to mobile-powered loyalty programmes, and the brands are increasingly looking towards improvising the functionalities of the mobile application (mobile app). It seems like the functionality of mobile apps is taken very seriously as customers would instead use the app, which has good features and useful functions. Close to 80 percent of millennials and nearly two-thirds of baby boomers have indicated their interest in getting rewards for purchases and even suggested that games should be integrated with mobile loyalty programmes (Burnett, 2019). Research published by P\&S Market Research stated that the global gamification market expected to touch USD22,913.00 million by 2022, and factors boosting the market to grow is due to the growing involvement of people in social sites, high adoption of gamification in corporate and growing penetration of gadgets and display devices (Global News Wire, 2017). Gamification is the application of game elements incorporated for users to earn rewards for their activities within the loyalty programmes to encourage customer loyalty and improve engagement (Business News Daily, 2020). Some of the most well-known mobile loyalty programmes introduced in the United States are Starbucks, Amazon Prime and Kohl (Johnson, 2019). This proves to show that customer preferences are also changing together with technological advancements as the current information systems are only promoting easy access to information and convenient usage of technology to better their daily lives. On the other hand, in the United Kingdom, the research 
found that 90 percent of consumers belong to at least one loyalty programme and that the UK is one of the most mature loyalty markets in the world (Rigby, 2018). Brands are increasingly thinking of mobile-first when creating, and growing customer loyalty. Kerem Atasoy, the Head of Digital Marketing for Harvey Nichol said that the launch of its mobilebased loyalty programme was based on research with customers that showed 80 percent preferred a mobile app to a plastic card (Bacon, 2015). Similarly, Tesco UK is expected to improve the digital functionality of its 20 over year old loyalty scheme club card (Bacon, 2015).

As far as Malaysia is concerned, a study revealed that 88 percent of the Malaysian population uses smartphones, 76 percent of them are active internet users, and 83 percent of the internet users access the internet every day (Social, 2018). That is a higher percentage of the population that uses smartphones than with the American smartphone users stated above. In 2019, 75 percent of the internet users spent their money via e-commerce with 58 percent spending on mobile commerce platforms, and this provides a unique opportunity for businesses. This proves to show that customers do have the knowledge and ability to perform the task in an advanced technological products or features, thus proving technology selfefficacy in customers is improving (Bernama, 2019). It was also reported that ride-hailing mobile applications proved to be very popular in Malaysia, ranking the third highest globally behind Singapore (Bernama, 2019). Chan Kok Long, the co-founder of Ipay88 (the payment gateway leader in Malaysia), stated that mobile commerce (m-commerce) is growing tremendously. Chan Kok Long predicted that the next thing that will be trending in Malaysia is the mobile-wallets and China's top players, Alipay and WeChat Pay will contribute to the online transactions in Malaysia (Bernama, 2019). The advanced infrastructure, strategic position and encouraging policies of Malaysia opens opportunities for businesses to implement such technological advancements (Retail News Asia, 2017). Interestingly, BMW Group Malaysia, an automobile company, had introduced a mobile loyalty application for its members to access their privileges. The app also enables easier integration of e-payment, financing services, and access to luxury events. The company also aims to further digitalise its products, services, and touchpoints through the mobile app to engage with customers (The Sun Daily, 2018). This is relatively uncommon for the automobile industry; however, due to the demand for digitalisation and with studies revealing a significant percentage of customers using smartphones to mobile applications to internet usage, it is indeed the right time for companies to explore and be competitive. Therefore, companies should leverage on the advancing technology and provide better services.

Customer loyalty is the positive attitude portrayed by customers towards a product or service provider resulting in repeat purchase behaviour which is often measured with attitudinal and behavioural aspects to differentiate between a faithful loyal customer and spurious loyalty (Boateng, 2019). However, there is no specific factor that has been said to be the influencing factor of customer loyalty. For instance, Kandampully, Zhang, \& Bilgihan (2015) asserted that customer engagement and satisfaction would enable companies to establish an emotionally loyal customer base. Therefore, the theory of customer loyalty lacks a definite scale to measure, and this includes a gap of knowledge concerning mobile loyalty programmes. Many studies may have looked into loyalty programmes; nevertheless, with technological advancements; it is crucial to provide practical solutions to fill in the gap for mobile loyalty programmes on customer loyalty. The main objective of this paper is to determine variables related to customer loyalty concerning mobile loyalty programmes and to identify factors that would contribute to customer loyalty with mobile loyalty programmes. 


\section{Research Objectives}

The main objective of this study is to develop a research framework for mobile loyalty programmes based on previous studies concerning particularly on customer loyalty upon the post-adoption stage. This is because many companies are already exploring mobile advertising, and it is crucial for companies to ensure that the application is relevant to the customers. Not only that, but with the implementation of the mobile loyalty programme, companies must ensure that the platform is as per the needs of customers and it provides convenience in their daily lives. It should be beyond just a physical card and leverage the adoption of this new technology for the betterment of the companies to maintain long-term customer relationships.

\section{Literature Review}

According to Law \& Ng (2016), the use and adoption of new technologies have been a topic of discussion for a very long time. Researchers generally investigate the determinants of user acceptance of the various new technologies with theoretical models such as the Theory of Reasoned Action (TRA) by Fishbein and Ajzen (1975), the Theory of Planned Behaviour (TPB) by Azjen (1985), and the Technology Acceptance Model (TAM) by Davis (1989) (Law \& Ng, 2016). Among these, the Theory of Planned Behaviour (TPB) is regarded as one of the most popular models cited in the field of predicting human social behaviour (Ajzen, 1991a). It is so popular that from 22 citations in 1985, the number of citations grown 4,550 in 2010 based on Google Scholar search for the keyword 'Theory of Planned Behaviour' (Ajzen, 2011). The TPB model has been able to predict a wide range of behaviours and has been commonly used in the prediction of health-related behaviour in industries like health and environmental science ( $\mathrm{Si}$ et al., 2019; Sommer, 2011). In fact, the TAM model is a combination of the TRA and TPB theories which is considered to be an influential model in explaining technological adoption behaviours (Law \& $\mathrm{Ng}$, 2016).

The TPB model is an extension of the Theory of Reasoned Action (TRA) model due to its limitations in dealing with behaviours over which people have incomplete volitional control (Ajzen, 1985). According to Frith (2013), volitional control is the ability for an individual to decide or choose between different actions. The main focus of the TPB model is the individual's intention to perform a given behaviour which can be identified as an individual's willingness to try to perform the final outcome (Ajzen, 1991a). The intention here can be viewed from motivational elements such as an individual's effort or commitment to involve and engage with the behaviour (Mohd Noor, Sreenivasan, \& Ismail, 2013). The TPB model, as shown in Figure 1, explains that an individual's behavioural intention is a function of attitude toward the behaviour, subjective norm, and perceived behavioural control (Fishbein \& Ajzen, 1975). 


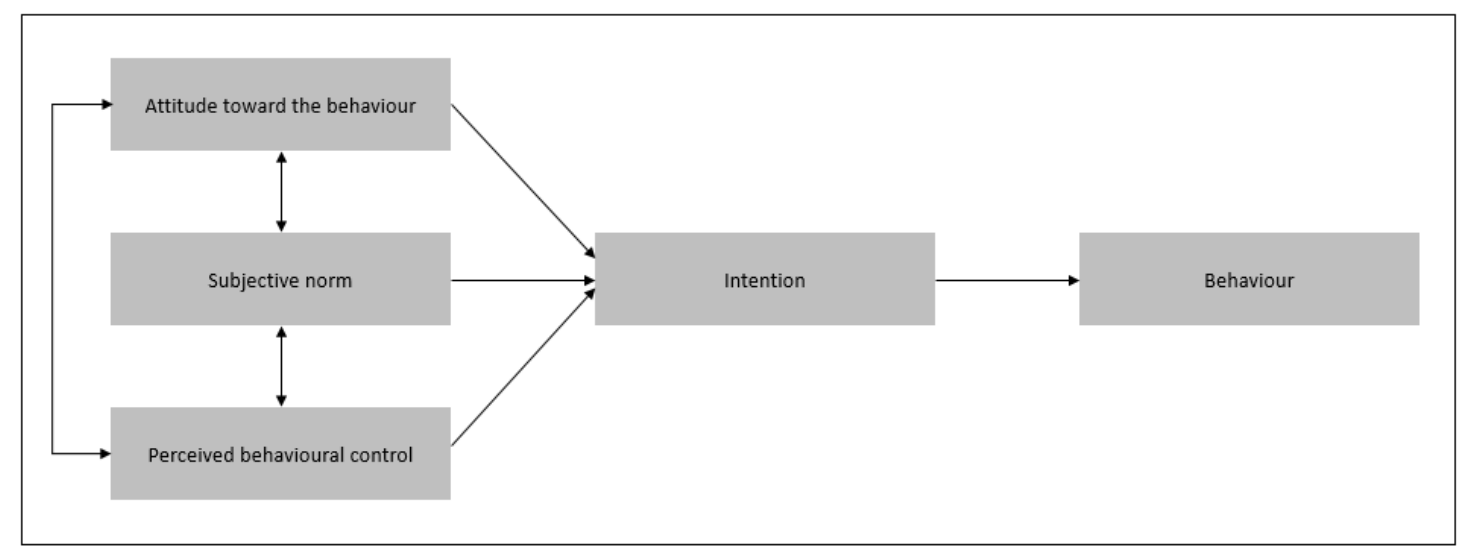

Figure 1: The Theory of Planned Behaviour Source: (Ajzen, 1991a)

\section{Attitude towards the Behaviour}

The first determinant of intention discussed in the TPB model is the attitude towards the behaviour, and is defined as "the degree to which a person has a favourable or unfavourable evaluation or appraisal of the behaviour in question (Ajzen, 1991b). This means that if an individual feels a positive attitude towards a behaviour, he or she will also have a positive intention. According to Noor et al. (2013), attitudes develop reasonably from the beliefs people hold about the object of the attitude. Priya, Baisya, \& Sharmab(2010) stated that by watching in-app advertisements, the cognitive and affective attitudes toward in-app advertisements are dominant and therefore affect users' behaviour to look for more knowledge. In the context of the mobile loyalty programme, users are driven (positive attitude) to download and use the mobile application due to its functions and outcome. For instance, AirAsia's Big loyalty apps enable its members (customers who have sign-up for the loyalty programme) to not only purchase AirAsia flight tickets but also to purchase products and services at other participating merchants (partnering brands) to earn big points. The points earned can be redeemed with other products and services, thus indicating the prediction of intention.

\section{Subjective Norm}

The second determinant is the social factor named as the subjective norm, and is defined as "the perceived social pressure to perform or not to perform the behaviour" (Ajzen, 1991b). Taylor \& Todd (1995) stated that subjective norm seen as equivalent to social influences because individuals define other peoples' opinions and superior influences as psychological motives of behaviours. Besides, it can be seen as the social pressure that individuals perceive to perform a particular behaviour (Gómez-Ramirez, Valencia-Arias, \& Duque, 2019). The social pressure can be from family, friends, colleagues, or even the Key Opinion Leaders (KOL). Key opinion leaders are mainly individuals who are trusted by relevant interest groups on social platforms (blogs and social media sites), and they have significant effects on consumer behaviour, especially of those avid social media users (Haroon, 2020). This further proves Ajzen's (1991a) findings that the more favourable the subjective norm of an individual's behaviour, the stronger it will be on his or her intention to perform the behaviour. In the context of the mobile loyalty programme, the more people provide positive reviews or feedback regarding the brand's mobile application, the more possibly users wish to adopt the app's usage and subsequently stay loyal to the brand. 


\section{Perceived Behavioural Control}

The perceived behavioural control refers to the perception that people generally have about the ease or difficulty of performing the behaviour, and it is assumed to reflect upon past experience and obstacles (Ajzen, 1991a). This is the determinant that was included as an extension of the TRA model to ensure a behaviour is controlled. For instance, even if an individual has a positive attitude and feels towards social pressure, he or she will not have behavioural intention without the knowledge or even money (J. H. Kim \& Lee, 2019). Besides, the individual's perception includes resources, knowledge based on past experiences and facilitating conditions (Belkhamza \& Niasin, 2017). According to Venkatesh, Morris, Davis, \& Davis (2003), facilitating conditions refer to which extent people believe that an organizational and technical infrastructure exists to support the use of innovation. In the context of the mobile loyalty programme, brands generally provide user-friendly interface to support the facilitating conditions thus eliminating negative user perception towards the brand.

Therefore, it is believed that the more positive a person's attitude, subjective norm, and perceived behavioural control, the more consumers will have the tendency to perform a behaviour (Ajzen, 1991a). Moreover, the interesting fact about this model is that intentions may not necessarily be determined by the three main determinants discussed above but also other possible variables which one can identify and assess the intentions and behaviour (Ajzen, 2011). Besides, the TPB model was used as the basis and core component of many other newly developed models such as Chau \& $\mathrm{Hu}$ (2002) united the factor of peer influence with the TAM model while Awa, Ojiabo, \& Emecheta (2015) integrated TAM, TPB and Technology-organization-environment model (TOE) to further comprehend e-commerce adoption by small and medium scale enterprises (SMEs). Despite the growing interest and importance placed on understanding consumer attitudes, intention and behaviours with mobile applications and their potential impact as a mobile commerce, the most recent study by McLean, Osei-Frimpong, Al-Nabhani, \& Marriott (2020) examine the antecedents and outcomes of consumer attitudes towards retailers' mobile commerce applications at initial adoption and during continuous use. One of the TPB model's biggest strengths is that it has been the core foundation of many researchers to evaluate users' behaviour on the usage of information systems which may vary from mobile applications to marketing analytical tools to financial analytical tools and other technology-based systems. Therefore, it is crucial to evaluate consumer behaviour from different perspectives in order to comprehend the topic thoroughly.

\section{Research Methodology}

The research adhered to a systematic method to the content search by first conducting extensive study on mobile loyalty programmes in Malaysia. The investigation was conducted through Google search with selection content related to news only. A total of 40,900 results appeared, showcasing updates on brands from various industries. In order to further understand the environment of the topic, the search explicitly restricted specifically to Food \& Beverage industry. The results showcased a mixture of data concerning mobile loyalty programmes and the performance of branded loyalty programmes in the market both locally and internationally. This provided an overview of the situation and enabled the researcher to comprehend the market environment of the topic area, issues concerning loyalty 
programmes, and the development of the dependent variable (customer loyalty) for this study.

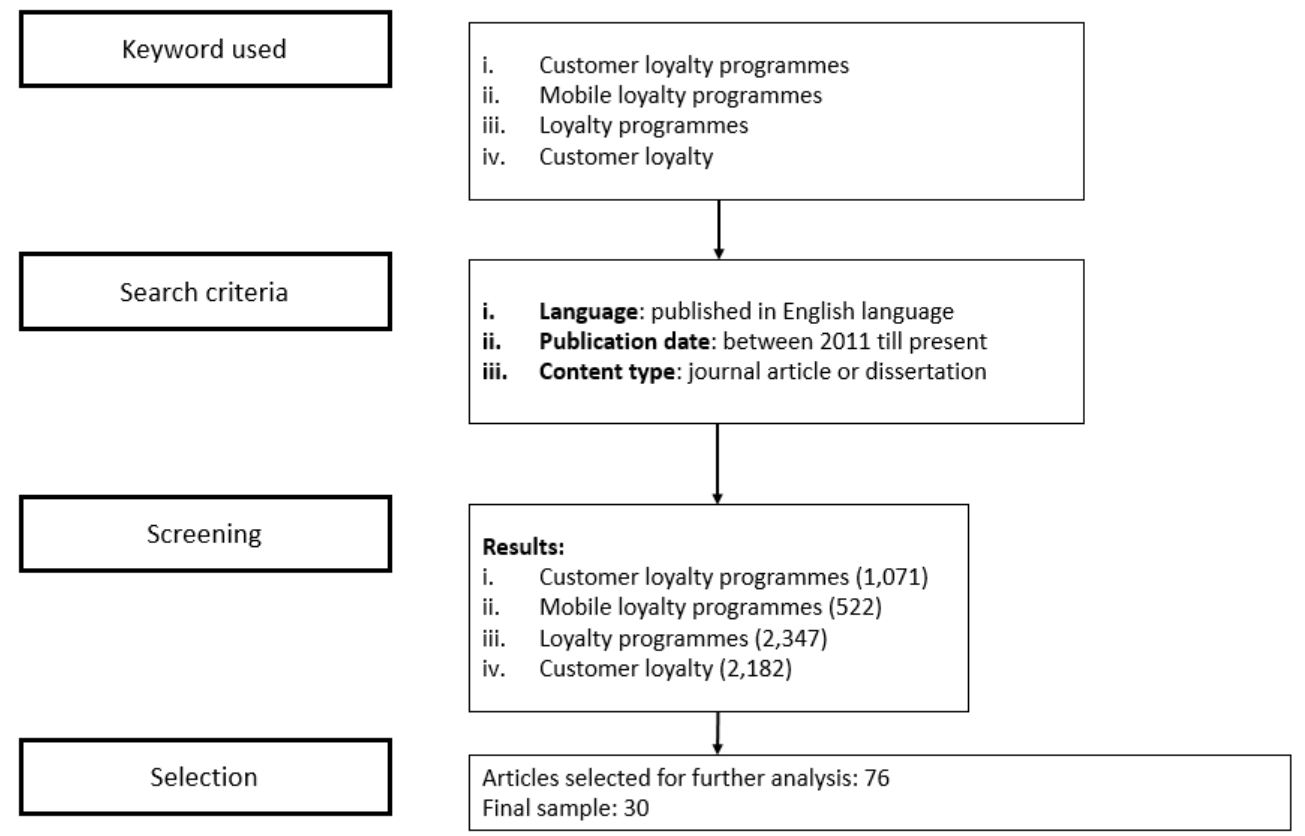

Figure 2: Methods to search for literature

With that, the researcher extended the search to focus on particularly literature content relevant to understanding consumer behaviour related to technology and their loyalty status post the implementation of the mobile loyalty programmes. The research was conducted through Google Scholar and from the online library of INTI International College and University which provided access to e-resources such as EBSCO, Science Direct, ProQuest and Emerald. Although the research for mobile loyalty programmes produced limited results for journal articles, relevant articles supported the mobile application adoption or usage and users' loyalty status with the brand. The keywords used for this study include customer loyalty programmes, mobile loyalty programmes, customer loyalty, and loyalty programmes. In order to identify the most relevant journal articles, the search focused on particularly academic publications written in the English language and articles within the last ten years (2011 to the current year 2021). The research resulted in 1,071 articles for keyword customer loyalty programmes, 522 for mobile loyalty programmes, 2,347 for loyalty programmes and 2,181 for customer loyalty. A screening process was conducted to evaluate the relevancy of the article with Theory of Planned Behaviour and, most importantly articles which are recognised as scientific journals. A total of 30 articles were finally selected as it fulfils the objective of this research.

\section{Findings}

In contributing to the literature on the adoption and post usage of mobile loyalty programmes, this paper undertakes an analysis to review other research findings related to loyalty programme or usage of the types of theories and models. This is to comprehend the outcome of the research which are mainly continuance usage or customer loyalty. The majority of the study related to mobile loyalty programmes did not focus specifically on one type of industry as the results may vary depending on the research nature and objectives. For instance, studies were conducted within the industry of apparel, education, health, travel, fashion, medical and hotel (Carter \& Yeo, 2016; Dale, White, Mitchell, \& Faulkner, 2019; S. J. 
Kim, Wang, \& Malthouse, 2015; Thakur, 2019). Where else some researchers opted for general industry to evaluate consumers' attitude towards mobile commerce, and adoption on mobile loyalty applications (Singh, Zolkepli, \& Kit, 2018; Yang, 2013). Another study focused on specific branded applications like Starbucks, Eva Airlines, 7-Eleven, Lion Travel and MUJI in order to evaluate the influence of brand competence on mobile app continuance and brand loyalty.

There is an evident that the research type may also contribute to more profound insight on the topic as the analysis shows the majority of the study was undertaken with quantitative approach mainly survey questionnaire. While some opted for a qualitative and a mixed-mode (Carter \& Yeo, 2016; Kim et al., 2015). For instance, the study of Baek \& Yoo (2018) used both focus group interview, expert review and an online survey with undergraduate students to develop a reliable and valid measure of branded app usability which incorporates consumer perceptions. Moreover, this research also aims to highlight that within the context of mobile applications; researchers have utilised or adopted different theories and models to support their findings. Most studies that aim to comprehend consumer attitudes towards the usage of branded mobile apps adopted TAM, and TPB models (Carter \& Yeo, 2016; McLean, 2018; Singh et al., 2018; Yang, 2013). There were other studies that integrated models such as UTAUT, SDL and VIU model and ECT theory to understand consumer intention with the use of mobile apps (Fang, 2019; Jeon, Ali, \& Lee, 2019; Thakur, 2019). Besides, understanding consumer behaviour during the adoption and post-adoption stage of the loyalty programme is also crucial to assist practitioners in developing appropriate strategies that will help meet consumers' needs. For instance, the research of Kim et al. (2015) focuses on airline loyalty programme mobile app of consumer post-adoption stage to further understand the spending level of these users against non-users to evaluate their spending behaviour.

Some of the commonly used variables and outcomes in the past researches and its findings discussed as below: -

i. $\quad$ Perceived Ease of Use

Perceived ease of use is generally used as the independent variable to examine consumers' attitudes towards the brand and loyalty towards the brand in which; the study confirmed that said antecedent positively influences consumers' attitude towards the branded mobile commerce application (McLean, 2018). Another study which intended to understand the factors that influence attitude towards mobile commerce and its factors found that perceived ease of use has a strong coefficient towards the mobile commerce adoption and supports that the TAM model is still relevant in marketing research (Singh et al., 2018). While factoring into a specific target audience, mainly young Americans in the adoption of mobile applications show that perceived ease of use has a significant influence on mobile app usage (Yang, 2013). One may argue that results may vary based on specific industry; however a study that was conducted within the medical industry indicated high usage of intensity with perceived ease of use on medical professionals' usage of the mobile app (Veríssimo, 2018).

\section{ii. Subjective Norm}

It is crucial to point out that the TPB model is still relevant to current studies. As such, one of its variable, subjective norm, is tested to evaluate the consumers' app usage behaviour, specifically with business undergraduates and postgraduates (Carter \& Yeo, 2016). The results indicated more differences between the two groups where undergraduates were more 
influenced by friends and family on the attitudes while postgraduates looked less to friends for support and preferred to do further research on the apps themselves (Carter \& Yeo, 2016). This indicates that not all consumers will favour or rely on recommendations or influences surrounding them. Focusing on the younger generation, influences of friends and family are crucial in deciding what's appropriate for them. In contrast, the older generations can make decisions based on their preferences. For instance, the study of young Americans on the adoption of mobile applications indicated that subjective norm strongly influences the attitudes towards app usage (Yang, 2013).

Users' intention to watch in-app ads was positive and significant between subjective norm and behavioural responses (Cheung \& To, 2017). This indicates that the opinion of others does matter even when it is related to in-app ads, which may be regarded as intrusive for some. Nevertheless, a study by Jeon et al (2019) shows that social influence did not show significant influence on consumers' intentions to use the flight booking application. This is because consumers are already well aware of the usage of travel apps to book flights, and therefore, social influence were not applicable in current situation. For instance, the study indicated that consumers' intentions to adopt apps for flight booking is strong with facilitating conditions as they have the resources and knowledge to use the app (Jeon et al., 2019). In another study, peer influence was used as the independent variable to examine medical professionals' usage of the mobile app and the results show low significant in the actual behaviour to continuous usage of the mobile app (Veríssimo, 2018).

\section{iii. Attitude towards the Behaviour}

Attitude is also another variable widely used and the studies were to evaluate consumers' attitude toward the behaviour of mobile app adoption or continuous usage. For instance, Carter \& Yeo (2016) examined consumer attitude with moral, ethical, frequency, zero cost effect, stable connectivity, clear vision and spacious screens and data entry proficiency on towards app usage behaviour. The results indicated strong influence and more similarities between undergraduates and postgraduates regarding of their apps usage behaviour. Another study examined mobile commerce adoption by constructing attitude as the mediating variable in the study (Singh et al., 2018).

The results revealed that all three independent variables (perceived usefulness, perceived ease of use, perceived trust and perceived self-efficacy) strongly influence mobile commerce adoption through their attitude towards the app (Singh et al., 2018). It is believed that attitude is a strong and direct antecedent to predict consumer usage behaviour (Singh et al., 2018). This is supported by the study of Yang (2013) in which independent variables such as perceived usefulness, subjective norm, ease of use, perceived enjoyment and perceived expressiveness positively predict their attitudes toward mobile apps. Attitude in this study was used as the mediating variable, and it positively supported consumers' behaviour towards mobile apps usage. In fact, when evaluated through trust, it leads to favourable attitudes towards in-app ads, thus results in desirable behaviour (Cheung \& To, 2017). The users' intention to watch in-app ads was positive and significant to their attitudes.

\section{iv. Engagement}

Customer engagement was examined in the study of Lee \& Lee (2019) the mediating variable of cognitive benefits, hedonic benefits, and social benefits to understand brand loyalty. The study integrated the Uses and Gratifications theory to comprehend the relationships among benefits in branded hotel apps, engagement, brand trust and brand 
loyalty (Lee \& Lee, 2019). Results show that all three variables positively influenced customers' engagement. Even with the use of the TAM model, the findings confirm that engagement with branded mobile applications positively influences customers' attitudes towards the brand and loyalty towards the brand (McLean, 2018).

Besides, it is also to be noted that consumers using the m-commerce application at home are more influenced to engage with the app due to the level of enjoyment received from their experience. Another study used engagement in the form of intrinsic enjoyment as the moderating role in satisfaction-loyalty relationship in the mobile application environment, specifically for shopping and travel planning (Thakur, 2019). The study revealed that intrinsic enjoyment has significant interaction effects for e-WOM and continuance intention. Thus, engagement as the predictor of customer loyalty should be used for future researches as previous studies indicated positive results.

Based on the previous literature review, this study proposes three independent variables within the setting of customer loyalty for mobile loyalty programmes.

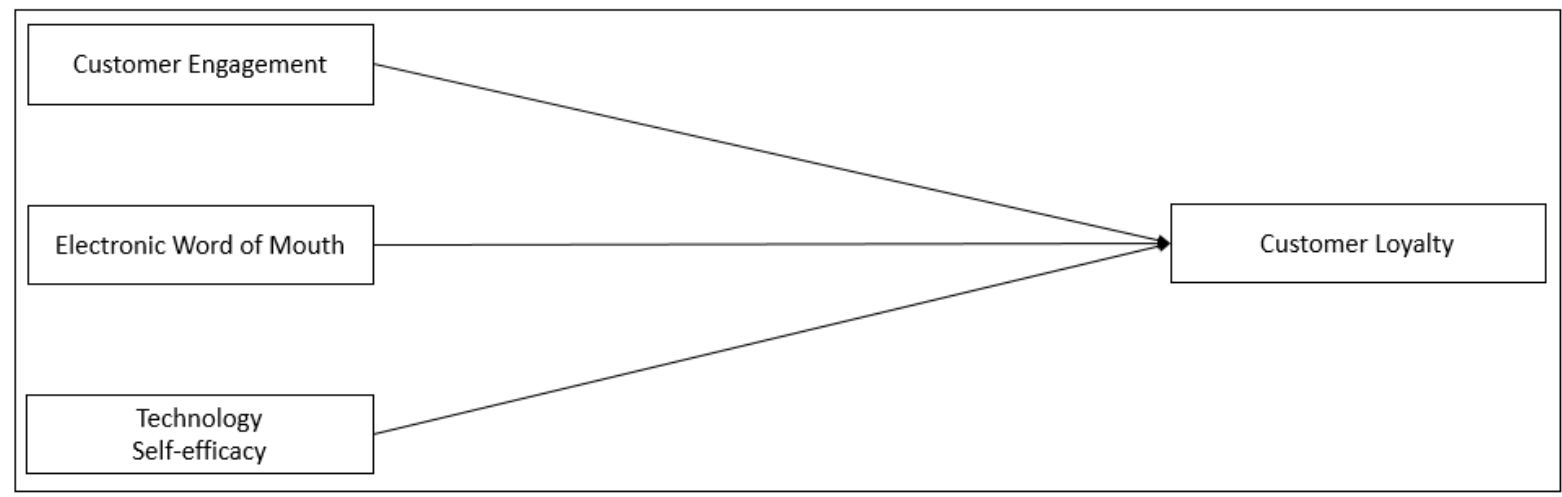

Figure 3: Proposed Conceptual Framework

\section{Conclusion}

This study intended to provide an overview of customer loyalty within the context of mobile loyalty programmes. Most importantly, this review is sought to identify antecedents or rather the research framework which can help brands to maintain and increase customer loyalty. Theory application is also essential as in this research, the Theory of Planned Behaviour was used as the basis of comprehending customers' intention to perform favourable behaviour towards the brand concerning the mobile loyalty programmes. Besides, the research method conducted will shed light on the possibilities of keywords that can be related to mobile loyalty programmes and strategies for selecting the relevant articles concerning the research topic. This literature review may offer discussion amongst marketing industry practitioners in evaluating the relevancy of mobile loyalty programmes which aimed to improve customer loyalty towards the brand. For instance, the ability to understand the customer perception or rather acceptance on mobile loyalty programmes instead of the traditional physical card. Based on the analysis of the existing works of literature, perceived ease of use, attitude, subjective norm, and engagement are popular variables used by researchers in the mobile loyalty programme studies. The variation in results from one research to another indicates the importance of multiple tests pertaining to the variables to find a rigorous model for the future. 


\section{Acknowledgement}

This study was truly guided by Dr. Mohd Nazri Mohd Noor, Director for IQM Open University Malaysia. I would like to express my profound gratitude to Dr. Mohd Nazri who is my supervisor for his commitment and deep insights in all aspects. I am extremely grateful for his constant encouragement and guidance.

\section{Corresponding Author}

Sharlini Seridaran (PhD Candidate)

Open University Malaysia, Malaysia

Email: Sharlini.seridaran@gmail.com

\section{References}

Ajzen, I. (1985). From Intentions to Actions: A Theory of Planned Behavior. In Action Control. https://doi.org/10.1007/978-3-642-69746-3_2

Ajzen, I. (1991a). The theory of planned behavior. Organizational Behavior and Human Decision Processes. https://doi.org/10.1016/0749-5978(91)90020-T

Ajzen, I. (1991b). The theory of planned behavior. Organizational Behavior and Human Decision Processes, 50(2), 179-211. https://doi.org/10.1016/0749-5978(91)90020-T

Ajzen, I. (2011). The theory of planned behaviour: Reactions and reflections. Psychology and Health, 26(9), 1113-1127. https://doi.org/10.1080/08870446.2011.613995

Awa, H. O., Ojiabo, O. U., \& Emecheta, B. C. (2015). Integrating TAM, TPB and TOE frameworks and expanding their characteristic constructs for e-commerce adoption by SMEs. Journal of Science and Technology Policy Management, 6(1), 76-94. https://doi.org/10.1108/JSTPM-04-2014-0012

Bacon, J. (2015). Is the future for loyalty schemes in mobile apps? Retrieved from https://www.marketingweek.com/is-the-future-for-loyalty-schemes-in-mobile-apps/

Baek, T. H., \& Yoo, C. Y. (2018). Branded App Usability: Conceptualization, Measurement, and Prediction of Consumer Loyalty. Journal of Advertising , 47(1), 70-82. https://doi.org/10.1080/00913367.2017.1405755

Belch, G., \& Belch, M. (2018). Advertising and Promotion: An Integrated Marketing Communications Perspective (11th ed.). Retrieved from http://books.google.com/books?id=rFhCPgAACAAJ\&pgis=1

Belkhamza, Z., \& Niasin, M. A. F. (2017). The effect of privacy concerns on smartphone app purchase in Malaysia: Extending the theory of Planned Behavior. International Journal of Interactive Mobile Technologies, 11(5), 178-194.

https://doi.org/10.3991/ijim.v11i5.6961

Bernama. (2019). Malaysia ranks top 5 globally in mobile social media penetration, highest in region. Retrieved from https://www.nst.com.my/lifestyle/bots/2019/01/456119/malaysia-ranks-top-5globally-mobile-social-media-penetration-highest

Boateng, S. L. (2019). Online relationship marketing and customer loyalty: a signaling theory perspective. International Journal of Bank Marketing, 37(1), 226-240. https://doi.org/10.1108/IJBM-01-2018-0009

Burnett, S. (2019). Mobile Loyalty Isn't Coming, It's Already Here. Retrieved from https://www.forbes.com/sites/forbesagencycouncil/2019/03/01/mobile-loyalty-isntcoming-its-already-here/\#7a442277770e

Business News Daily. (2020). What Is Gamification? Retrieved December 16, 2020, from 
https://www.businessnewsdaily.com/4541-gamification.html

Carter, S., \& Yeo, A. C. M. (2016). Mobile apps usage by Malaysian business undergraduates and postgraduates: Implications for consumer behaviour theory and marketing practice. Internet Research, 26(3), 733-757. https://doi.org/10.1108/IntR-10-2014-0273

Chan, M. (2017). Petronas new points scheme for Mesra loyalty programme - up to 3x as many points as competition. Retrieved March 1, 2019, from

https://paultan.org/2017/11/18/petronas-new-points-scheme-for-mesra-loyaltyprogramme-up-to-3x-as-many-points-as-competition/

Cheung, M. F. Y., \& To, W. M. (2017). The influence of the propensity to trust on mobile users' attitudes toward in-app advertisements: An extension of the theory of planned behavior. Computers in Human Behavior, 76, 102-111. https://doi.org/10.1016/j.chb.2017.07.011

Dale, L. P., White, L., Mitchell, M., \& Faulkner, G. (2019). Smartphone app uses loyalty point incentives and push notifications to encourage influenza vaccine uptake. Vaccine, 37(32), 4594-4600. https://doi.org/10.1016/j.vaccine.2018.04.018

Fang, Y. H. (2019). An app a day keeps a customer connected: Explicating loyalty to brands and branded applications through the lens of affordance and service-dominant logic. Information and Management, 56(3), 377-391.

https://doi.org/10.1016/j.im.2018.07.011

Fishbein, M., \& Ajzen, I. (1975). Strategies of Change: Active Participation. Belief, Attitude, Intention, and Behavior: An Introduction to Theory and Research.

Frith, C. (2013). The psychology of volition. Experimental Brain Research. https://doi.org/10.1007/s00221-013-3407-6

Global News Wire. (2017). Gamification Market to Touch \$22.9 Billion by 2022: P\&S Market Research. Retrieved from https://www.globenewswire.com/newsrelease/2017/08/03/1071818/0/en/Gamification-Market-to-Touch-22-9-Billion-by2022-P-S-Market-Research.html

Gómez-Ramirez, I., Valencia-Arias, A., \& Duque, L. (2019). Approach to M-learning Acceptance Among University Students. The International Review of Research in Open and Distributed Learning, 20(3). https://doi.org/10.19173/irrodl.v20i4.4061

Haroon, R. (2020). Power of key opinion leaders. Retrieved May 21, 2020, from https://www.nst.com.my/opinion/columnists/2020/02/563797/power-key-opinionleaders

Hutchinson, K., Donnell, L. V., Gilmore, A., \& Reid, A. (2015). Loyalty card adoption in sme retailers: The impact upon marketing management. European Journal of Marketing. https://doi.org/10.1108/EJM-06-2013-0321

Jeon, H. M., Ali, F., \& Lee, S. W. (2019). Determinants of consumers' intentions to use smartphones apps for flight ticket bookings. Service Industries Journal, 39(5-6), 385-402. https://doi.org/10.1080/02642069.2018.1437908

Johnson, L. (2019). Top 10 mobile loyalty programs from first three quarters. Retrieved from https://www.retaildive.com/ex/mobilecommercedaily/top-10-mobile-loyaltyprograms-from-first-three-quarters

Kandampully, J., Zhang, T. (Christina), \& Bilgihan, A. (2015). Customer loyalty: A review and future directions with a special focus on the hospitality industry. International Journal of Contemporary Hospitality Management. https://doi.org/10.1108/IJCHM-03-2014-0151

Ker, N. (2020). Setel, the e-payment solution for petrol, is now available at Petronas stations nationwide. Retrieved December 16, 2020, from https://www.malaymail.com/news/money/2020/02/06/setel-the-e-payment-solution- 
for-petrol-is-now-available-nationwide/1834924

Kihlstrom, G. (2018). How Customer Loyalty Programs Can Enhance The Customer Experience. Retrieved from https://www.forbes.com/sites/forbesagencycouncil/2018/11/20/howcustomer-loyalty-programs-can-enhance-the-customer-experience/\#27d6b365a46d

Kim, J. H., \& Lee, H. C. (2019). Understanding the repurchase intention of premium economy passengers using an extended theory of planned behavior. Sustainability (Switzerland), 11(11). https://doi.org/10.3390/su11113213

Kim, S. J., Wang, R. J. H., \& Malthouse, E. C. (2015). The Effects of Adopting and Using a Brand's Mobile Application on Customers' Subsequent Purchase Behavior. Journal of Interactive Marketing, 31(2015), 28-41. https://doi.org/10.1016/j.intmar.2015.05.004

KPMG. (2019). The truth about customer loyalty. Retrieved December 16, 2020, from https://home.kpmg/xx/en/home/insights/2019/11/customer-loyalty-survey.html

Law, M., \& Ng, M. (2016). Age and gender differences: Understanding mature online users with the online purchase intention model. Journal of Global Scholars of Marketing Science, 26(3), 248-269. https://doi.org/10.1080/21639159.2016.1174540

Lee, S. A., \& Lee, J. (2019). Enhancing customers' brand loyalty via branded hotel apps. Journal of Quality Assurance in Hospitality and Tourism, 20(3), 339-361. https://doi.org/10.1080/1528008X.2018.1537819

McLean, G. (2018). Examining the determinants and outcomes of mobile app engagement - A longitudinal perspective. Computers in Human Behavior, 84, 392-403. https://doi.org/10.1016/j.chb.2018.03.015

McLean, G., Osei-Frimpong, K., Al-Nabhani, K., \& Marriott, H. (2020). Examining consumer attitudes towards retailers' m-commerce mobile applications - An initial adoption vs. continuous use perspective. Journal of Business Research, 106(August 2018), 139-157. https://doi.org/10.1016/j.jbusres.2019.08.032

Noor, M. N., Sreenivasan, J., \& Ismail, H. (2013). Malaysian consumers attitude towards mobile advertising, the role of permission and its impact on purchase intention: A structural equation modeling approach. Asian Social Science.

https://doi.org/10.5539/ass.v9n5p135

Mulqueen, T. (2018). Beyond Points: Companies Are Using Innovative Rewards Programs To Draw In Customers. Retrieved from https://www.forbes.com/sites/tinamulqueen/2018/08/01/beyond-points-companiesare-using-innovative-rewards-programs-to-draw-in-customers/\#26f029db732d

Priya, P., Baisya, R. K., \& Sharma, S. (2010). Television advertisements and children's buying behaviour. Marketing Intelligence and Planning, 28(2), 151-169.

https://doi.org/10.1108/02634501011029664

Retail News Asia. (2017). Malaysia sees mobile commerce boom as mobile payments become widely available. Retrieved September 20, 2003, from Retails News Asia website: https://www.retailnews.asia/malaysia-sees-mobile-commerce-boom-mobilepayments-become-widely-available/

Rigby, C. (2018). $90 \%$ of UK adults are part of a loyalty programme, while only $15 \%$ of retailers offer one: study. Retrieved from https://internetretailing.net/marketing/marketing/90of-uk-adults-are-part-of-a-loyalty-programme-while-only-15-of-retailers-offer-onestudy-18134

Si, H., Shi, J. G., Tang, D., Wen, S., Miao, W., \& Duan, K. (2019). Application of the theory of planned behavior in environmental science: a comprehensive bibliometric analysis. International Journal of Environmental Research and Public Health. 
https://doi.org/10.3390/ijerph16152788

Singh, S., Zolkepli, I. A., \& Kit, C. W. (2018). New wave in mobile commerce adoption via mobile applications in Malaysian market: Investigating the relationship between consumer acceptance, trust, and self efficacy. International Journal of Interactive Mobile Technologies, 12(7), 112-128. https://doi.org/10.3991/ijim.v12i7.8964

Social, W. A. (2018). Essential Insights into Internet, Social Media, Mobile, And E-Commerce Use Around the World. Retrieved from https://www.digitalinformationworld.com/2018/07/global-internet-statsinfographic.html

Sommer, L. (2011). The Theory Of Planned Behaviour And The Impact Of Past Behaviour. International Business \& Economics Research Journal (IBER), 10(1), 91-110. https://doi.org/10.19030/iber.v10i1.930

Taylor, S., \& Todd, P. A. (1995). Understanding information technology usage: A test of competing models. Information Systems Research. https://doi.org/10.1287/isre.6.2.144

Thakur, R. (2019). The moderating role of customer engagement experiences in customer satisfaction-loyalty relationship. European Journal of Marketing, 53(7), 1278-1310. https://doi.org/10.1108/EJM-11-2017-0895

The Sun Daily. (2018). BMW Group Loyalty+ Mobile App. Retrieved from https://www.thesundaily.my/archive/bmw-group-loyalty-mobile-app-NUARCH535801

Venkatesh, V., Morris, M. G., Davis, G. B., \& Davis, F. D. (2003). User acceptance of information technology: Toward a unified view. MIS Quarterly: Management Information Systems. https://doi.org/10.2307/30036540

Veríssimo, J. M. C. (2018). Usage intensity of mobile medical apps: A tale of two methods. Journal of Business Research, 89(December 2017), 442-447.

https://doi.org/10.1016/j.jbusres.2017.12.026

Warc. (2019). Dissecting loyalty in Malaysia. Retrieved December 16, 2020, from https://www-warc-com.ezproxy.herts.ac.uk/newsandopinion/news/dissecting-loyaltyin-malaysia/42600

Yang, H. C. (2013). Bon appétit for apps: Young American consumers' acceptance of mobile applications. Journal of Computer Information Systems, 53(3), 85-96. https://doi.org/10.1080/08874417.2013.11645635

Yuen, S. (2019). The challenges of maintaining customer loyalty amid endless brand choices. Retrieved December 16, 2020, from https://www.marketing-interactive.com/thechallenges-of-maintaining-customer-loyalty-amid-endless-brand-choices 